\title{
SELF-REGULATION IN THE SECURITIES INDUSTRY: THE ROLE OF THE SECURITIES AND EXCHANGE COMMISSION*
}

\author{
Richard W. JENNINGS†
}

Our pattern of federal securities control has traditionally placed great faith and reliance upon the principle of industry self-regulation. Long before the adoption of the Securities Exchange Act of $1934,{ }^{1}$ the stock exchanges had evolved a system of internal government regulating the admission and conduct of members. ${ }^{2}$ The Exchange Act built on this self-regulatory structure by placing initial responsibility for policing brokers and dealers who were members of an organized exchange upon that body.

Until I938, however, no similar organization existed with respect to securities firms engaged in an over-the-counter business. In that year the Securities and Exchange Commission (SEC) and the securities industry joined hands in promoting the formation of an institutional organization to administer a system of self-regulation with respect to firms doing an interstate securities business in the over-the-counter markets. ${ }^{3}$ This cooperation led to the joint sponsorship by the Commission and the Investment Bankers Conference (IBC) of legislation which culminated in the

- This article bears an authorship date of May 20, 1964 .

†A.B. 1927, Park College; A.M. I934, University of Pennsylvania; LL.B. r939, University of California, Berkeley. Coffroth Professor of Law, University of California, Berkeley. Member of the California bar.

${ }^{2} 48$ Stat. $88 \mathrm{I}$ (1934), 15 U.S.C. $\$ 78 \mathrm{a}$ (1958).

2 The organization typically, although not invariably, took the form of a voluntary unincorporated association. The constitution and bylaws prescribed rules for the admission, discipline and expulsion of members. These rules were regarded as a contract to which each member agreed to adhere. For one of the carliest reported American cases advancing the contract theory in connection with an organization of stock brokers, see White v. Brownell, 2 Daly 329, 4 Abb. Pr. (n.s.) I62 (C.P.N.Y. I868). Incorporation was eschewed for fear of judicial interference with the internal affairs of the association. Equity courts had intervened to prevent expulsion of a member of a corporation in extreme cases on the theory that the member had derived his rights by virtue of the statute creating the corporation, rather than by contract with the other members. A voluntary association, on the other hand, is not a creature of statute; and the privilege of membership was deemed to be conferred by the organization itself. Such voluntary bodies were allowed to prescribe their own rules. Where the rules were adhered to the body could discipline or expel a member; if the proceedings were regular and taken in good faith the courts refused to intervene. And see Belton v. Hatch, I09 N.Y. 593, I7 N.E. 225 (I888) (New York Stock Exchange); CharLes H. Meyer, The Law of Stockbrokers and Stock Exchanges 37-49 (I93I); Charles A. Dice \& Wilford J. Eiteman, The Stock Market 90-95 (2d ed. 194I).

'For the historical background of the Maloney Act and the National Association of Securities Dealers (NASD), see Securities and Exchange Commission, Report of Special Study of Secturities Markets, H.R. Doc. No. 95, 88th Cong., Ist Sess. pt. 4, at 604-07 (1963) [hereinafter cited as Special Study]; S. REP. No. 1455 and H.R. REP. 2307, 75th Cong., 3d Sess. (1938); address by SEC Chairman William 0 . Douglas before the Bond Club of Hartford, Conn., Jan. 7, 1938, in Conference News, published by Investment Bankers Conference, Inc., vol. I, No. IIA, Jan. 8, 1938; address by Senator Francis T. Maloney to California Security Dealers Association, Investment Bankers Association, and NASD, San Francisco, Aug. 22, 1939. 
passage of the Maloney Act, adding section $15 \mathrm{~A}$ to the Exchange Act. ${ }^{4}$ As a result of this legislation, the National Association of Securities Dealers (NASD) came into existence as a self-regulatory institution for the over-the-counter markets. Although membership in the NASD is purely voluntary, under the authority prescribed in section ${ }_{15} \mathrm{~A}(\mathrm{i})$ ( $\mathrm{x}$ ) of the Exchange Act an NASD rule precludes an NASD member from dealing with a non-member broker or dealer except at the prices and on the same terms and conditions accorded to members of the public.5 Thus, for all practical purposes, the vast majority of brokers or dealers in securities must be members of the NASD in order to engage profitably in most underwritings and over-thecounter business. ${ }^{\beta}$ At the same time, however, certain retail sales organizations which deal directly with the public rather than with other securities firms may engage in the securities business without the economic necessity of joining the NASD. These firms, which include certain large, integrated mutual fund retail sales organizations and retailers of securities issued by real estate syndicates, have refused to submit themselves to industry self-regulation by joining the NASD. With these exceptions, most of the securities firms of the country are members of one of the self-regulatory institutions through membership in a stock exchange or in the NASD.

Although important regulatory responsibilities are placed upon these self-governing institutions under the Exchange Act, the Commission is assigned the task of supervising the operation of this system of self-government. Furthermore, Congress gave it the reserve power to step in and regulate directly when dissatisfied with industry rules or practices. ${ }^{7}$ During the past thirty years, however, the Commission has been a rather tame watchdog; only once has it chosen to alter existing rules of the exchanges (as distinguished from its own rules) rather than wait for action by the industry. ${ }^{8}$ Thus, over the years, self-regulation has come to mean, at least to the

52 Stat. 1070 (1938), 15. U.S.C. $\$ 780-3$ (1958).

52 Stat. 1073 (1938), I5 U.S.C. \$ 780-3(i) (1958); NASD Rules of Fair Practice, art. III, § 25 , NASD Manual D-r3.

As of Dec. 3I, I962, the NASD membership constituted $4,77 \mathrm{I}$ firms or $83 \%$ of the 5,724 firms registered with the Commission under $\S$ I5 of the Exchange Act. A high percentage of the sceurities salesmen of the country, comprising some 94,444 individuals, was registered with the NASD as registered representatives. Special Study, pt. 4, at 603 .

${ }^{7}$ Section 19 (b) of the Exchange Act vests in the Commission power to alter or supplement exchange rules in respect of twelve specified areas of exchange operations. 48 Stat. 898 (1934), I5 U.S.C. $\$ 785$ (b) (1958). The Commission has similar power with respect to certain NASD rules. See $\$ 15 A(k)(2), 52$ Stat. 1074 ( 1938 ), I5 U.S.C. $\$ 780-3(\mathrm{k})(2)$ (r958). In addition, the Commission may abrogate any NASD rules when it finds that such abrogation is necessary or appropriate to assure fair dealing by the members of the NASD. See $\S x_{5} A(k)(1), 52$ Stat. 1074 (1938), 15 U.S.C. $\$ 780-3(k)(1)$ (1958). For a discussion of the Commission's powers in these areas, see p. 676 , infra. Section $\mathrm{II}$ authorizes the Commission to prescribe its own rules (I) "to regulate or prevent" floor trading; and (2) to prevent excessive off-floor trading by., exchange members. 48 .Stat. $89 \mathrm{r}$ (1934), as amended, 15 U.S.C. $\$ 78 \mathrm{k}$ (1958). The Commission has never adopted a rule under section II but has followed the practice of "suggesting" that the exchanges themselves adopt any necessary rules. 'The Commission, however, has recently given notice of a significant departure from this pattern; new proposed rule IIa-1, severely restricting floor trading, is to be issued as a Commission, rule. See. SEC Securities Exchange Act Relcase No. 7290, April 9, 1964 and note.rg infra. The New York Stock Exchange (NYSE) is to file a plan concerning floor trading which conforms to proposals previously made by the Commission. Failure to adhere to the plan will violate the Exchange Act rule.

8 The single occasion in which the Commission exercised its powers under $\$ 19(\mathrm{~b})$ occurred 
industry and particularly to the New York Stock Exchange (NYSE), that the SEC will observe a rather passive role, leaving the industry to govern itself in its own wisdom.

The bull market which began in 1956 and collapsed in May 1962, put this form of securities control to a severe test. In far too many instances there was a failure to track down wrongdoers until long after the damage had been done. In the case of the American Stock Exchange an after-the-fact investigation revealed a complete breakdown of industry self-regulation and the ineffectiveness of government oversight by the SEC. ${ }^{9}$ Even before this investigation was completed, however, Congress in" I96I had directed the Commission "to make a study and investigation of the adequacy, for the protection of investors, of the rules of the national securities exchanges and national securities associations, including rules for the expulsion, suspension, or disciplining of a member for conduct inconsistent with just and equitable principles of trade." The Commission was asked to make a report containing such recommendations for legislation as it deemed advisable. ${ }^{\text {io. }}$

This investigation culminated in the Report of the Special Study of the Securities Markets, the most comprehensive study of its kind yet made. Chapter I2 of the report concentrates on the system of self-government in the securities industry, evaluates the effectiveness of the various self-regulatory institutions-the New York Stock Exchange, the American Stock Exchange, the principal regional exchanges, the NASD and certain quasi-regulatory agencies-and assesses the role of the SEC as "supervisor" of these agencies." The report notes the absence of self-regulatory institutions in certain areas, primarily retailers of interests in mutual funds and real estate syndicates. It proposes that these gaps in the self-regulatory machinery be closed. ${ }^{12}$ The voluntary membership system of the NASD would be supplanted by a compulsory system under which all brokers and dealers using the mails to facilitate securities transactions, whether or not engaged in an interstate business, must join a self-regulatory organization, subject to the power of the Commission to grant exemptions where necessary or appropriate. These proposals have been embodied in the Commission's 1963 legislative program now before the Congress. ${ }^{13}$

\footnotetext{
when the NYSE refused to change its rules preventing a NYSE member from acting as an odd-lot dealer or specialist upon a regional exchange in securities listed on the NYSE and traded on both exchanges. In the Matter of the New York Stock Exchange, ro S.E.C. 27o (I94I). See Special Study, pt. 4 , at 704 .

- SEC Staff Report, Organization, Management, and Regulation of Conduct of Members of the American Stock Exchange (I962), reprinted in Special Study, pt. 4, at 75I-8I4. Since this socalled Amex report was issued, that exchange has undergone a thorough reorganization. See Hearings on H.R. 6789, H.R. 6793, S. ${ }_{1642}$ Before a Subcommittee of the House Committee on Interstate and Foreign Commerce, 88th Cong., Ist \& 2 d Sess., pt. I, at 4I7-600 ( $1963-64)$.

${ }^{10} 75$ Stat. 465 ( $196 \mathrm{r}$ ), as amended, I5 U.S.C. $\$ 78$ s (Supp. IV; 1962).

11 Special Study, pt. 4, at 495-750.

- ${ }^{12} 1 d$. at 692.

${ }^{13}$ See S. 1642 , H.R. 6789,88 th Cong., ist Sess. (1963). S. 1642 , with amendments, received a favorable report from the Committee on Banking and Currency. See S. REP. No. 379, 88th Cong., Ist Sess. (1963). The bill passed the Senate on July 30, 1963. H.R. 6793, representing H.R. 6789 with the Senate amendments, was referred to the Subcommittee on Commerce and Finance of the House Committee
} 
Certain other recommendations of the Special Study relate to stock exchange reform. These include the recommendation that floor trading be banned in phases starting in 1964 and concluding in $1965 ;^{14}$ that the specialist system be overhauled and subjected to more stringent regulation; ${ }^{15}$ and that certain changes be made in the odd-lot system. ${ }^{16}$ The Special Study strongly suggests that although the Commission should continue to give maximum scope to self-regulation wherever a regulation is needed, the Commission should close the gap between the total regulatory need and the quantity and quality of self-regulation, by exercising close supervision through changes in existing rules of the self-regulatory agencies and by direct regulation where self-regulation is inadequate. ${ }^{\mathbf{1 7}}$

This penetrating analysis of the operation of cooperative regulation, perhaps coupled with congressional encouragement or pressure, ${ }^{18}$ has apparently impelled the Commission to assert its reserve powers in order to correct certain abuses that have persisted, particularly in stock exchange practices. These moves on the part of the Commission have been met so far by the stiff resistance of the officials of the NYSE and the American Stock Exchange (Amex). The "Big Board" and the SEC have just gone through an eye-ball to eye-ball confrontation over the Commission's proposal to ban or greatly restrict floor trading. ${ }^{19}$ This showdown struggle over floor trading was heralded as the "biggest fight between the Big Board and the .. . Commission since New Deal days."20 The "bloodless triumph" gained by the Commission may foreshadow further changes in stock exchange rules and

on Interstate and Foreign Commerce. See Hearings on H.R. 6789, H.R. 6793, S. 1642, supra note 9, pts. 1-2. Both the Subcommittee and the full Committee made extensive changes in H.R. 6793. The bill, as amended, was reported out on May 19, 1964. H.R. REp. No. 1418, 88th Cong., 2d Sess. (1964).

14 Special Study, pt. 2, at 238-42.

${ }^{15}$ Id. at $16 \mathrm{r}-71$.

${ }^{10} \mathrm{Id}$. at 199-202.

${ }^{17}$ Special Study, pt. 4, at 722-28.

${ }^{18}$ See Kohlmeier, Wall Street Journal, Oct. 2, 1963, p. I2, col. 4. "It's understood that the Congress" men privately insisted to the SEC that the section [of the Special Study on "Self-Regulation and the Commission"] be included." Ibid.

${ }^{19}$ After a series of closed door meetings between NYSE officials and the SEC, it was reported that the Commission was likely to move soon to ban or sharply restrict floor trading by stock exchange members. Wall Street Journal, March Ir, 1964, p. 2, col. 3. On March I6, 1964, Mr. G. Keith Funston, President of the NYSE, advised the Exchange membership by letter that the Commission had broken off discussions with Exchange officials on an SEC proposal to "ban floor trading on the exchange or to restrict it so severely as to eliminate its benefits." NYSE News Relcase, March 16, 1964, p. 1. And sce N.Y. Times, March 16, 1964, p. 47, col. 6; Wall Street Journal, March 16, 1964, p. 2, col. 2. The Amex joined the Big Board in defending the floor traders on the ground that they "added substantial liquidity to markets that need liquidity and on balance ... have provided a stabilizing force." Wall Street Journal, March 17,1964 , p. 8, col. 3. A few days later the NYSE announced that the Board of Governors had approved in principle a series of changes in exchange rules governing floor trading. NYSE News Release, March 23, 1964; Wall Street Journal, March 20, 1964, p. 24, col. I; id., March 23, 1964, p. 3 col. 1. This move did not satisfy the SEC which countered with a proposal to issue its own rules restricting floor trading and hold public hearings thercon. N.Y. Times, March 24, 1964, p. 45, cols. I and 8; id., April 6, I964, p. 45, col. 3. On April 8, 1964 the Commission announced new proposed rule r1a-1 making a fundamental change in SEC control of floor trading; and the NYSE announced that they would go along with the new rules. SEC Securities Exchange Act Release No. 7290, April 9, 1964; N.Y. Times, April 9, 1964, p. 1, col. 1; id., p. 41, col. 6; id., p. 48, cols. 2 and 5.

so Wall Street Journal, March 25,1964, p. 26 , col. 2. 
practices in problem areas and may indicate an attempt to shift the balance of power within the stock exchange membership itself so as to lessen the disproportionate influence of the floor professionals in the government of the Exchange as compared with the brokerage firms that deal directly with the public. ${ }^{21}$

This new-found firmness on the part of the Commission, which has been construed in some quarters as an "attack on Wall Street,"22 makes a reappraisal of the relative roles of the industry and the Commission in the self-regulatory system particularly timely. In this paper an attempt will be made to review the historical basis of the self-regulatory principle and the intent of congressional legislation. Attention will also be given to the problems posed by this dual system of regulation, including costs and duplication of effort, as well as the practical values arising from industry involvement and participation. Finally, consideration will be given to what improvements may be made in the system in order to render investor protection more effective without unduly hampering legitimate business.

\section{I}

\section{Evolution of the Self-Regulatory System}

\section{A. The Exchanges}

Prior to the enactment of the Exchange Act, in 1934, the stock exchanges of the country were subject to little or no external regulation. As voluntary associations they were treated by the law as private clubs. The constitution and bylaws were held to express a "contract by which each member had consented to be bound, and which measures his duties, rights and privileges."2s

The exchanges also maintained a strict control over dealings between members and nonmembers in several ways. The quotations of transactions on an exchange are essential to firms engaged in the securities business. The exchanges early contracted with communications companies to furnish quotations, subject to the condition that the ticker service be made available only to such persons as the exchange approved. The courts held that although such quotations could not be copyrighted, ${ }^{24}$ they were the property of the exchange entitled to protection as a trade secret. ${ }^{25}$ State courts differed as to whether an exchange or communication medium might discriminate as between applicants for quotation service. ${ }^{26}$ However, in 1926 the United States Supreme Court held that the exchange was not bound to make its

${ }^{32}$ N.Y. Times, April 9, 1964, p. 41, col. 6; see Special Study, pt. 4, at 571. This study focuses mainly on the NYSE, although the same points apply in varying degree to the Amex and the regional exchanges.

"See editorial, "The Attack on Wall Street," Wall Street Journal, April 2, 1964, p. 12, col. 4.

ss Belton v. Hatch, supra note 2, at 596 , i7 N.E. at 226.

"National Tel. News Co. v. Western Union Tel. Co., Irg Fed. 294 (7th Cir. 1902).

${ }^{26}$ Moore v. New York Cotton Exch., 270 U.S. 593 (1926).

so The Illinois Supreme Court held that market quotations were clothed with a public interest and ruled that they must be furnished to all on equal terms. New York \& Chicago Grain \& Stock Exch. v. Board of Trade, 127 Ill. 153, 19 N.E. 855 (1889). The New York courts took a contrary view. Matter of Renville, 46 App. Div. 37, 61 N.Y. Supp. 549 (1899). Sec Meyer, op. cit. supra note 2, at 49-60. 
quotations generally available to all persons willing to pay for the service: "In furnishing the quotations to one and refusing to furnish them to another, the exchange is but exercising the ordinary right of a private vendor of news or other property."27 Until recently, the NYSE also forbade its members to establish private direct wire or other connections with nonmembers without prior consent of the Exchange. Discontinuance of any such connections could be compelled at any time. ${ }^{28}$ Last.year, however, in Silver $v$. New York Stock Exchange, ${ }^{20}$ the Supreme Court held that the collective action of the Exchange in ordering a member to discontinue private wire connections with a nonmember, without affording the nonmember a hearing and an opportunity to refute any charge of misconduct, violates the antitrust laws. As a result of the Silver decision, the NYSE no longer refuses ticker service to nonmembers. Anyone who wants this service may have it by paying for it at standard rates. ${ }^{30}$

The status of the Big Board as a private club created some concern that personal rather than public interests dominated exchange government. As early as Igog the Hughes Commission ${ }^{31}$ had been urged to recommend that the NYSE be incorporated in order "to bring it more completely under the authority and supervision of the State and the process of the courts."32 The Hughes Commission rejected this view "in the expectation that the Exchange . . . will be active in preventing wrongdoing such as has occurred in the past."33

At the federal level, the Pujo Committee ${ }^{34}$ investigated the need for government regulation of the stock exchanges prior to the outbreak of World War I. The Pujo Committee discovered that the authorities of the NYSE were aware of various manipulative practices, including pool operations, and that no effective measures to prevent such practices were taken. ${ }^{35}$ Nevertheless, the Exchange insisted that it still should be permitted to continue to operate as a voluntary organization "with the

${ }^{27}$ Moore v. New York Cotton Exch., supra note 25, at 605.

${ }^{28}$ NYSE Rule 355, suspended Sept. 20, r96r. 2 CCH NYSE Guide I 2355.

20373 U.S. 34I, 365 (1963).

${ }^{80}$ See testimony of Mr. G. Keith Funston, President of the New York Stock Exchange, in Hearings on H.R. 6789, H.R. 6793, S. 1642, supra note 9, pt. I, at 37r. The Exchange still restriets the use which may be made of quotations in order to protect its interest in them. See NYSE Rule 359,2 CCH NYSE GUIDE \2359.

${ }^{31}$ This commission was appointed by Charles Evans Hughes, then Governor of New York, to report on stock exchange speculation following the panic of 1907. The report of the commission appears in William C. VAN ANTwerp, The Stock Exchange from Within 4I5-46 (1913). And sce Meyer, The New York Stock Exchange and the Panic of 1907, 18 YALE Rev. 34 (1909).

${ }^{33}$ VAN ANTWERP, op. cit. supra note 31, at 427. The commission noted that as a voluntary organization the exchange had "almost unlimited power over the conduct of its members"; this feature was thought to possess the advantage of speed in handling disciplinary problems while preserving substantial justice for the membership. The commission was of the view that the spirit of comradeship among members had led them to overlook misconduct on the part of fellow-members, and that there had been a failure to take proper measures to prevent wrongdoing. Ibid.

${ }^{33}$ Ibid.

${ }^{34}$ Hearings Before the Subcommittee of the House Committee on Banking and Currency on Investigation of Financial and Monetary Conditions in the United States Under House Resolutions Nos. 429 and 504 (Money Trust Investigation), 62d Cong., 2d Sess. (1913).

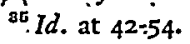


privileges and freedom of action of a private club and should not be made subject to legislative or judicial control or supervision." ${ }^{36}$ The Committee disagreed and recommended that the Exchange be required to incorporate and that it be subjected to federal regulation. ${ }^{37}$ Nothing came of these proposals.

Matters stood in this posture in 1934 when the Exchange Act was before the Congress. The stock market crash and subsequent exposures by congressional investigation had made federal stock market control inevitable. ${ }^{38}$ The battle was pitched in terms of the degree of federal intervention in exchange government and the extent to which the exchanges would be allowed to function under a system of self-regulation. At the direction of President Roosevelt, Secretary of Commerce Roper had appointed an interdepartmental committee on stock exchange regulation. $^{39}$ The committee reported in January 1934 , recommending the establishment of a federal stock exchange authority to license stock exchanges. Use of the mails and interstate facilities would be forbidden to exchanges not licensed by the authority. The Committee stressed the desirability of leaving a large measure of initiative and responsibility to the exchanges with the stock exchange authority possessing the "authority to move quickly and to the point when the necessity arises."40

The original bill, ${ }^{41}$ which ultimately became the Exchange Act, went further in the direction of direct regulation of the exchanges. It would have forbidden a stock exchange firm that acted as a broker to act as a dealer or underwriter in securities. ${ }^{42}$ It would also have banned floor trading. Specialists were to be prohibited from executing market orders and from trading for their own account as dealers. ${ }^{43}$

Opposition to these sweeping proposals arose from within the Roosevelt administration. John Dickinson, Chairman of the Roper Committee, became the leading spokesman in favor of building on the system of self-regulation. It was his theory that "if governmental regulation attempts to do too much directly and to control and intervene directly in the first instance over the whole field which it covers, it is in danger of breaking down under its own weight and proving ineffective." ${ }^{4}$

${ }^{30}$ Id. at II5.

${ }^{37}$ Ibid.

${ }^{98}$ See Hearings Before the Senate Committee on Banking and Currency on Stock Exchange Practices, 73d Cong., xst Sess. (1933); S. Rep. No. 1455, 73d Cong., zd Sess. (1934); Ferdinand Pecora, Waiz STREET UNDER OATH (I939).

${ }^{30}$ The Roper Committee consisted of Messrs. John Dickinson, Assistant Secretary of Commerce, as Chairman, and A. A. Berle, Arthur H. Dean, and Henry J. Richardson, a Washington lawyer. For the report, see Stafi of Senate Comm. on Banking and Currency, 73D Cong., 2d Sess., Stock Exchange Regulation, Letter from President to Chatrasan of Committee on Banking and Currency with an Accompanying Report Relative to Stock Exchange Regulations (Comm. Print 1934); also printed in N.Y. Times, Jan. 28, 1934, p. 24, col. 2.

${ }^{10}$ Ibid.

${ }^{41}$ H.R. 7852 . See Hearing on H.R, 7852 and 8720 , Stock Exchange Regulation, Before the House Committee on Interstate and Foreign Commerce, 73d Cong.; 2d Sess. I-15. (1934).

${ }^{2}$ Id. at $7, \S$ ro. This provision followed the recommendation of a study conducted by the Twentieth Century Fund in 1933-34. Twentieth Century Fund, Inc., The Security Markets 674 (I935).

"Hearing on H.R. 7852 and H.R. 8720, Stock Exchange Regulation, supra note $4 \mathrm{I}$ at 7, 124, 508.

"Id. at 513 . 
The functions of the governmental agency charged with regulating the stock exchanges were to be "held in reserve" and "employed only to supplement and supervise what in the first instance was self-regulation of the exchanges."45 Dickinson admitted that there was some truth in the charge "that the idea of self-regulation is just a device to avoid regulation." Even so, he believed that it was a "necessary recourse in view of the mere physical limitations in time and in personnel, which operate on the direct exercise of the powers of government as the task of regulation becomes more and more extensive over a wider and wider field." ${ }^{46}$

As a result of these criticisms and strong opposition from the securities industry and the business community, a compromise was struck. ${ }^{47}$ Under the Exchange Act, as it finally emerged, exchanges are required to register with the SEC in order for such exchanges or their members to use the mails or interstate facilities to effect transactions in securities or to transmit quotations. ${ }^{48}$ As a condition to registration, each registered exchange must agree "to comply, and to enforce so far as is within its powers compliance by its members," with the Exchange Act and any rules issued thereunder. ${ }^{49}$ Furthermore, the rules of the exchange must include provisions "for the expulsion, suspension, or disciplining of a member for conduct ... inconsistent with just and equitable principles of trade," and must declare that the willful violation of the Exchange Act or any rules thereunder "shall be considered conduct ... inconsistent with just and equitable principles of trade."100 The act does not in specific terms compel a registered exchange to submit rule changes to the Commission for approval prior to adoption; however, the exchange must make available to the Commission any amendments in exchange rules upon their adoption. ${ }^{61}$

45 Ibid.

${ }^{10} \mathrm{Id}$. at 514. Mr. Dickinson recognized that the exchanges would frequently fail to do a good job in regulating their members. Government regulation, however, should be applied to make the exchanges enforce discipline "and to come down on them like a ton of bricks if they did not do their job, rather than for the Government itself to take over from them that job of direct regulation and attempt to perform it from the very beginning and in the first instance by governmental policing methods." lbid.

${ }^{17}$ After three weeks of hearings on the original bill, H.R. 8720 was drafted to meet what were regarded as legitimate criticisms. See Hearing on H.R. 7852 and H.R. 8720 , Stock Exchange Regulation, supre note $4 \mathrm{I}$, at 625 .

${ }^{\$ 8}$ Securities Exchange Act $\$ 5,48$ Stat. 885 (1934), I5 U.S.C. $\$ 78 \mathrm{e}$ (1958).

${ }^{10}$ Securities Exchange Act $\$ 6(\mathrm{a})(1), 48$ Stat. 885 (1934), I5 U.S.C. $\$ 78 \mathrm{f}(\mathrm{a})(\mathrm{I})$ (1958).

"o Securities Exchange Act $\$ 6(\mathrm{~b}), 4^{8}$ Stat. 886 (1934), 15 U.S.C. $\$ 78 \mathrm{f}$ (b) (1958).

${ }^{51}$ Securities Exchange Act $\$ 6(2)(4), 4^{8}$ Stat. 886 (1934), 15 U.S.C. $\$ 78 f(a)$ (4) (1958). Sinco 1956, by informal agreement, the NYSE has given the Commission two weeks' notice of rule changes prior to their effectiveness. Special Study, pt. 4, at $7 \times x$. Nevertheless, the provision in $56(2)$ (4) that copies shall be furnished "forthwith upon their adoption" created a nagging doubt that the Commission was not entitled to advance riotice. In Silver v. New York Stock Exch., supra note 29, at 357, however, the Court with full awareness of $\$ 6(a)$ (4) stated that the power conferred on the Commission by $\$ 19(b)$, supra note 8 , to request exchanges to make changes in their rules impliedly gives the Commission the power to disapprove any rule adopted by an exchange. The Commission thereafter gave notice of proposed new rule I7a-8 which would require a registered exchange to file with the Commission any proposed change in its rules at least three weeks before effectiveness. SEC Securities Exchange Act Release No. 7218, Jan. 10, 1964. The SEC General Counsel finds the statutory authority under $\$$ I7 (a) of the Exchange Act, 48 Stat.

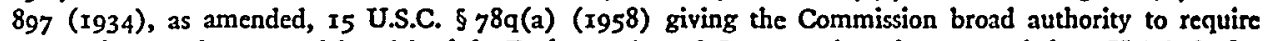
reports from exchanges and $\$ 23$ (a) of the Exchange Act, 48 Stat. 901 (1934), as amended, I5 U.S.C. $\$ 78 \mathrm{w}$ (1958). See SEC Gerieral Counsel's Memorandum, Hearings on H.R. 6789, H.R. 6793, S. 1642, supra 
Section Ig vests the Commission with certain powers over registered exchanges to obtain compliance with the Exchange Act and rules thereunder. The Commission may suspend an exchange for a period not exceeding twelve months for violations of the Exchange Act and rules thereunder or for failure to enforce, so far as is within its powers, compliance therewith by stock exchange members or issuers of listed securities. The Commission may also suspend for a period of not more than twelve months, or expel a member or officer of an exchange, if such person is found to have violated the Exchange Act or rules. The power to close the exchange is a far too drastic sanction, except under the most unusual circumstances; however, these sanctions provide the Commission with the mechanisms to compel compliance with its own rules.

The Commission has the power in certain areas set forth in the margin to initiate specific changes in the rules and practices of a registered exchange if after a request, notice and opportunity for hearing the exchange fails to act. ${ }^{52}$ Such action may be taken if the Commission finds that such changes are "necessary or appropriate for the protection of investors or to insure fair dealing in securities" traded over the exchange or "to insure fair administration" of the exchange.

Finally, under section in the Commission may make rules in the public interest or for the protection of investors (I) "to regulate or prevent" floor trading by members of registered exchanges for their own account or for discretionary accounts, and (2) to prevent such excessive off-floor trading by exchange members as it determines to be detrimental to the maintenance of a fair and orderly market. ${ }^{\text {53 }}$ Similarly, the Commission may regulate specialists and odd-lot dealers who must be registered as such. Moreover, specialists apparently may be prohibited from dealing for their own account; for if under SEC rules a specialist "is permitted to act as a dealer," such rules shall restrict his dealings "to those reasonably necessary to permit him to maintain a fair and orderly market." "83a

This statutory pattern presents certain anomalies. Although the Commission may discipline a member of an exchange for violation of the Exchange Act or rules,

note 9, pt. 2, at I070. The NYSE rejects this view. On the basis, however, that the proposed rule is only a reporting requirement rather than an attempt to assert the authority to delay an exchange from the exercise of its rule-making powers, the Exchange has decided not to oppose adoption of the rule or contest its validity. See letters of G. Keith Funston, President of the New York Stock Exchange, to Chairman Harlcy O. Staggers of the House Subcommittee and to SEC Commissioner William L. Cary, id. at Ir37-38.

${ }^{83}$ Securities Exchange Act $\S 19(\mathrm{~b})$, stupra note 7. These embrace "such matters as" (I) financial responsibility of members; (2) restriction of registration or trading in new issues for a specified period after issuance; (3) listing or delisting of securities; (4) hours of trading; (5) manner, method and place of soliciting business; (6) fictitious or numbered accounts; (7) matters concerning settlements, payments, and deliveries and of closing accounts; (8) reporting of transactions both on and outside of the exchange; (9) fixing of reasonable commission rates and other charges; (IO) minimum units of trading; (II) odd-lot transactions; (12) minimum deposits on margin accounts; and (13) similar matters. The wording implies that the enumeration does not exhaust the Commission's powers.

sa $\$$ II (a), supra note 7. Exemptions may be extended to transactions by odd-lot dealers and specialists.

s8a Securities Exchange Act $\$$ II(b), stupra note 7 . 
it may not compel him to comply with the rules of the exchange..$^{54}$ Furthermore, the Exchange Act does not prescribe procedures of registered exchanges applicable in discipline cases, nor does it provide for Commission review, on its own motion or upon application of an aggrieved person, of an exchange's enforcement activitics. ${ }^{\text {t5 }}$

Shortly after the adoption of the Exchange Act and during the chairmanship of Mr. Joseph P. Kennedy, the Commission made a comprehensive survey of the activities of specialists, floor traders, and odd-lot dealers on the NYSE and other exchanges. The Commission then formulated "suggested" rules for the regulation of trading on the exchanges. These rules were sent to registered exchanges with the Commission's request that they be adopted as rules of the exchange. Most registered exchanges adopted the rules as recommended or with slight modifications. $^{56}$ These rules were designed to make it more difficult to sell short on a falling market by forbidding short sales below the last reported sale. The specialist system was continued, thus permitting a member registered as specialist in one or more stocks to act as a broker for other members in the execution of customer orders, as well as to deal in such stocks for his own account. A specialist combining the functions of broker and dealer, however, could trade for his own account, only where reasonably necessary in order to enable him "to maintain a fair and orderly market."

These efforts at self-regulation failed to accomplish their objective in full measure..$^{57}$ It is true that an interpretation of the rules frequently entailed the application of subjective standards. Of more significance, however, was the fact that the governing board of the Exchange was dominated by the specialists and floor traders, the very groups most affected by the trading rules, whereas commission brokers who deal directly with the public had little effective representation. ${ }^{68}$ Added to this was the "private club" relationship between members, as a result of which members showed an extreme reluctance to punish fellow members caught breaking the rules. ${ }^{59}$ Furthermore, the Exchange has always surrounded disciplinary pro-

\footnotetext{
54 Although the Commission in theory might suspend the exchange for failure to cnforce its disciplinary rules, we have already seen that this would be throwing the baby out with the bath.

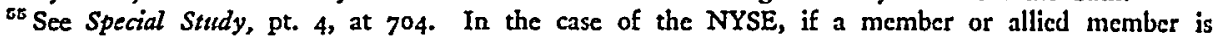
found guilty of fraudulent acts by a decision of a majority of the boand of governors, he must be expelled from the Exchange. For other violations of the Exchange's rules, the board may impose penalties of censure, fine (not exceeding $\$ 5,000$ ), suspension or expulsion. Id. at 538 .

${ }^{2}$ I SEC ANN. REP. 13-14 (1935). The rules may be found in id. 40-44. And see William 0 . Douglas, Democracy and Finance 66 (Allen ed. 1940).

${ }^{57}$ In 1938 , the Commission abandoned the self-regulatory approach to the control of short sales and promulgated its own rules pursuant to authority granted in section ro(a) of the Exchange Act. 48 Stat. 891 (1934), I5 U.S.C. $\$ 78 j$ (a) (1958). See note 108 infra.

${ }^{\circ}$ The Commission recognized the need for change in the rules of the exchanges in order to give greater representation in exchange government to commission firms, as a means of insuring better enforcement of disciplinary rules. See its report to Congress, in January 1935. H.R. Doc. No. 85, 74th Cong., Ist Sess. I7 (1935). The proposal was directed primarily at the NYSE; it cnvisaged "voluntary" action by the exchanges rather than direct regulation. See Special Study, pt. 4, at 506.

${ }^{80}$ See Dovelas, op. cit. supre note. 56, at 65. The Special Study observes that this tendency persists: "In the disciplinary area-the handling of revealed violations-the Exchange leans toward tenderness rather than severity. ..." Special Study, pt. 4, at 574 .
} 
ceedings with a wall of secrecy. Even today, actions taken against members and allied members are not publicly reported, except in cases of suspension or expulsion. ${ }^{60}$ In 1937, when Mr. William O. Douglas assumed the chairmanship of the Commission, he opened negotiations with the NYSE looking toward a reorganization of its internal government. ${ }^{61}$ Commission studies had led Mr. Douglas to conclude that the operations of the floor trader, the specialist and the odd-lot dealer had resulted in a number of abuses. For example, Commission statistics showed that there was a strong tendency for the floor professionals (both specialists and floor traders) to accentuate market swings by selling short for speculative profit at a time when the market was declining and buying heavily on margin in an upward swing, thus exerting a destabilizing influence which contributed to the severity of price fluctuations. Furthermore, at crucial times, the odd-lot dealers failed to pass on to the round-lot market a substantial part of the market support supplied by customers' purchases. ${ }^{62}$ These professional traders as a group dominated the Exchange government and blocked any reform that might limit their profit opportunities.

When the Exchange refused to budge, Chairman Douglas issued a public statement warning the Exchange to put its house in order by means of self-regulation or face more pervasive direct regulation by the Commission under the powers granted in the Exchange Act. ${ }^{63}$ Shortly thereafter, the President of the Exchange announced the appointment of the Conway Committee to study the organization and administration of the Exchange and make recommendations. ${ }^{84}$

The report of the Conway Committee, in January 1937, recommended sweeping changes in Exchange government and operating methods. The Board of Governors was to be reorganized to include office partners of member firms, both those based in New York City and out-of-town, and three new members appointed to represent the public. The administration of the affairs of the Exchange by the use of volunteers was to be supplanted by the development of a professional staff. A nonmember full-time paid president was to be elected with authority to appoint all officers except the chairman and vice chairman of the board of governors. A permanent executive staff was to be developed under the direct supervision of the president to administer Exchange affairs on a business-like basis thus relieving board members of administrative details and enabling them to concentrate on policy. These recommendations were approved by the Exchange membership and by May $193^{8}$ had become effective. ${ }^{65}$

Further important changes in the constitution and policies of the Exchange

${ }^{\circ 0}$ Id. at $540-42,574$.

${ }^{-1}$ See Dovglas, op. cit. supra note 56, at 64-73; Jennings, Mr. Justice Douglas: His Influence on Corporate and Securities Regulation, 73 YALE L.J. 920, 944-47 (1964).

as Dovglas, op. cit. supra note 56 , at $67-71$.

${ }^{\circ}$ N.Y. Times, Nov. 24, 1937, p. I, col. 5; id., p. 31, col. 2. Dovglas, op. cit. supra note 56, at 63-73.

OSee 4 SEC ANN. REP. 20-22 (1938).

${ }^{\circ}$ Special Study, pt. 4, at 506-09. 
occurred in I949-50. These changes were initiated by a group of floor members known as the Committee of $\mathrm{x} 7$. The object was to improve the position of the floor members in the Exchange power structure vis à vis other member blocs. The board of governors was increased to thirty-three members, its present size; certain floor trading rules which it was claimed inhibited a free auction market were repealed; and the constitution was amended to provide that a 2-year interval must elapse before re-election to the board of governors after two terms of service. ${ }^{06}$

Unquestionably the administration of the affairs of the New York Stock Exchange over the years has been of a very high order. Nevertheless, the recent conflict between the Exchange and the SEC over floor trading again brings into sharp focus the unsolved problems remaining with respect to specialists, odd-lot dealers, and commission rates, including the problem of quantity discounts for volume purchases. The Special Study investigation of the Exchange as a self-regulatory institution rates its performance quite high, but points out that there is still an unsatisfactory discharge of function in some areas. In assessing the reasons for failure of the system in certain respects the Special Study cites the disproportionate number of floor professionals in the government of the Exchange, stemming ultimately from the allocation of voting power under the Exchange constitution. ${ }^{07}$ These floor professionals are naturally primarily interested in their own activities on the trading floor as contrasted with those governors associated with member firms engaged primarily in a public brokerage business. ${ }^{08}$

${ }^{\circ 1} 1 d$. at 508. The board of governors consists of the chairman, president, three public members and twenty-eight members in three specific categories: ( 1 ) I $_{3}$ regular members, who must be based in New York; (2) 5 allied members and one regular member, all of whom must be New York based and be affiliated with brokers conducting business with the public; and (3) 9 regular or allied members, cach of whom must be affliated with an out-of-town firm which conducts a brokerage business with the public. Thus I4 governors must be regular members bolding a seat on the Exchange and 23 may be of this category. Id. at 509 .

${ }^{87} I d$. at $57 \mathrm{I}$. The right to vote in elections and on constitutional changes is limited to holders of a seat ("regular members") of the Exchange. There are 1,366 seats, all of which must be "owned" by an individual. Some 668 of these are owned by floor professionals, 648 by member firm partners and 5o seats are inactive. Id. at 518 .

${ }^{68}$ The recent announcement of the nominees for election to the Exchange's Board of Governors has raised speculation whether the choices refect an effort to meet SEC criticism. The present board, excluding the president and public members, consists of 7 specialists, 4 floor partners, one independent broker, and 17 non-floor members. The new mix would consist of 6 specialists, 5 floor partners, onc independent broker, and $\mathbf{1} 7$ members or allied members who are affiliated with firms doing a public brokerage business. It is believed that no great significance is to be attached to this slight change in composition.

The Special Study recommended that the disproportionate influence by the floor professionals arising from limiting voting rights to regular members holding "scats" on the Exchange could be reduced by giving full or partial voting rights to allied members, that is, partners and voting stockholders of member organizations. Special Study, pt. 4 , at 576 . It is understood that the Exchange has arranged to invite allied members to the quarterly membership meetings, which heretofore have been limited to full-fledged members. Wall Street Journal, April $\mathrm{r}_{4}, 1964, \mathrm{p}$. 6 , col. 2. There have even been rumors of a "revolt" by the big brokerage firms who are demanding greater representation on the board of governors for off-floor members. Time, April r7, 1964, p. 104, col. 3. 


\section{B. The National Association of Securities Dealers}

The statutory pattern providing for self-regulation of the NASD differs markedly from that of the exchanges. ${ }^{69}$ Whereas the stock exchanges have resisted governmental oversight, the NASD is an outgrowth of a desire by responsible representatives of the over-the-counter business for some form of industry self-regulation with oversight by the Commission. Furthermore, the industry concluded that the objectives of the organization could not be attained without implementing legislation, particularly legislation providing an exemption from the antitrust laws. ${ }^{70}$ As a result, the pattern of regulation represents improvements and refinements over the r934 formula applicable to the stock exchanges.

Section $15-\mathrm{A}$ of the Exchange Act contemplates the registration of associations of brokers or dealers as a national securities association if certain conditions are met. The NASD is the only association so far registered under this section. A registered association must open its membership to any broker or dealer who uses the mails or interstate facilities to effect transactions in securities otherwise than on a national securities exchange, with certain exceptions. In general, the rules of the association must deny membership to any broker or dealer if he (or any partner, officer, director or branch manager, or person in a control relationship) has previously been, or is thereafter, suspended or expelled from a national securities exchange for violation of any rule of the exchange which constitutes "conduct inconsistent with just and equitable principles of trade." Membership is similarly to be denied if the broker-dealer or any such affiliated person (a) is the subject of an SEC order denying or revoking his broker-dealer registration under section 15 of the Exchange Act, or suspending or expelling him from membership in a registered securities association (NASD) or a national securities exchange, or (b) has engaged in conduct as employee, agent, or person in a control relationship, which was the cause of any such currently effective order of an exchange, registered association, or the Commission. ${ }^{71}$

The association rules must also be "designed to prevent fraudulent and manipulative acts and practices, to promote just and equitable principles of trade . . and, in general, to protect investors and the public interest, and to remove impediments to and perfect the mechanism of a free and open market...."72 They must also assure fair representation to the membership in the administration of its affairs and provide for the equitable allocation of dues among members. ${ }^{73}$ Finally, provision must be

\footnotetext{
${ }^{\circ 0}$ For background material on the Maloney Act and the venture in cooperative regulation of the over-the-counter markets, see Jennings, supra note $6 \mathrm{I}$ at 947-5I; note 3 supra.

${ }^{70}$ See Special Study, pt. 4, at 604-07.

${ }^{71}$ Securities Exchange Act $\$$ I5A(b) (4), 52 Stat. I070 (1938), ${ }_{5}$ U.S.C. $\$ 780-3$ (b) (4) (1958). The rules may also restrict membership on a geographical basis or upon the type of business done by its members, or on such other basis as the Commission approves as being in the public interest or for the protection of investors or to effectuate the self-regulatory purposes. $\$ 15 A(b)(3), 52$ Stat. 1070 (1938), I $_{5}$ U.S.C. $\$ 780-3$ (b) (3) (1958).

${ }^{72}$ Securities Exchange Act $\$ 15 A(b)(7), 52$ Stat. 1071 (1938), 15 U.S.C. $\$ 780-3$ (b)(7) (1958).

${ }^{78}$ Securities Exchange Act $\$ 15 A(b)(5)-(6), 52$ Stat. I07I $(1938)$, I5 U.S.C. $\$ 780-(b)(5)-(6)$ (1958).
} 
made for disciplining of members for violation of the rules and for the establishment of fair and orderly procedures relating to matters of discipline and denial of membership. ${ }^{74}$

We have seen that the stock exchanges are completely free from external controls by the SEC or the courts in disciplinary matters, subject to possible restrictions arising under the antitrust laws. In contrast, section $15 \mathrm{~A}$ gives the Commission the authority, on its own motion, or upon application of any aggrieved person, to review disciplinary actions against any member of the NASD or denials of admission to that organization. ${ }^{75}$ After notice and hearing the Commission may sustain the action taken by the NASD or it may reduce or eliminate the penalty if it is found to be excessive or oppressive, but such penalty may not be increased. ${ }^{70}$ This departure from the pattern applicable to the stock exchanges seems an important and necessary ingredient of any system of industry self-regulation.

A further departure from the pattern applicable to the stock exchanges is to be found in the duty of the NASD to file subsequent rule changes or additions with the Commission prior to their effectiveness. If the Commission determines that such change or addition is not consistent with the requirements for original registration of the association, it may enter an order of disapproval; otherwise the new rule becomes effective thirty days after filing or such earlier date as the Commission permits. ${ }^{77}$

On the other hand, the Commission has far less authority to alter or supplement NASD rules than it has with respect to exchanges under section 19 (b). Under section I5A(k) the Commission has very limited powers to alter substantive rules of registered associations. Its powers are largely restricted to abrogating, altering or supplementing existing rules where necessary to ensure (I) fair representation of members in the administration of the association's affairs, and (2) fair procedures for admission and discipline of members, and in elections. The Commission also may abrogate any rule if necessary "to assure fair dealing by the members of such association ... or otherwise to protect investors or effectuate the purposes of the Exchange Act. $^{78}$ However, under section 15, providing for the registration of brokers and dealers, the Commission has rule-making powers with respect to the over-the-counter markets somewhat comparable to those under section $\mathrm{I} 9$ (b) with respect to exchanges. ${ }^{79}$ Thus, the Commission may exercise its rule-making power to outlaw acts or practices which it deems to be fraudulent, deceptive, manipulative, or in-

\footnotetext{
"Securities Exchange Act $\$ 15 A(b)$ (9), 52 Stat. 1071, (1938), 15 U.S.C. $\$ 780-3$ (b) (9) (1958).

${ }^{75}$ The institution of review proceedings operates as a stay of such action until the Commission disposes of the matter. Securities Exchange Act \$ $15 \mathrm{~A}(\mathrm{~g})$, 52 Stat. 1073 (1938), 15 U.S.C. $5780-3$ (g) (1958). The proposed legislation now before Congress would make the granting of a stay discretionary with the Commission. See note I $_{3}$ supra.

${ }^{76}$ Securities Exchange Act $\$ \$ 15 \mathrm{~A}(\mathrm{~g})$-(h), 52 Stat. ro73 (1938), 15 U.S.C. $\$ 780-3(\mathrm{~g})$-(h) (1958).

$\pi$ Securities Exchange Act $\$ 15 A(j), 52$ Stat. 1074 (1938), I5 U.S.C. $\$ 780-3(j)$ (1958).

${ }^{78}$ Securities Exchange Act $515 \mathrm{~A}(\mathrm{k})(\mathrm{I}), 52$ Stat. 1074 (1938), I5 U.S.C. $\$ 780-3(\mathrm{k})$ (1) (1958).

${ }^{70}$ Securities Exchange Act $\$ \times 5$ (c), 52 Stat. 1075 (1938), 15 U.S.C. $\$ 780$ (c) (1958).
} 
volving fictitious quotations. It may also erect safeguards relating to the financial responsibility of brokers and dealers.

This diversity of treatment of the exchanges, on the one hand, and the NASD, on the other, arises in part from historical reasons and in part from the fact that the later Maloney Act represents a substantial advance over the pattern of selfregulation applicable to the stock exchanges. Two new developments, the Silver case and the current proposal that all brokers and dealers using the mails for securities transactions belong to a section I5A registered association, heighten the need to re-evaluate the various supervisory powers which the SEC should exercise over these agencies of self-government. Proposals will now be advanced for improvement of SEC oversight over the stock exchanges and other self-regulatory securities associations.

\section{II}

\section{Proposals For IMPROVEMENT}

The self-regulatory philosophy is deeply imbedded in our system of securities regulation. It has the overwhelming support of the industry; and the Special Study recommends its continuance as a part of the total regulatory process. ${ }^{80}$ Nevertheless, some of the supposed advantages of self-regulation are by no means clear. It has generally been assumed that direct regulation would result in a pronounced expansion of the Commission's staff; the multiplication of branch offices; a large increase in the expenditure of public funds; and the substitution of the evils of bureaucracy for the efficiency of private groups. ${ }^{81}$ Experience has shown, however, that self-regulation itself requires the expenditure of very substantial funds which must be borne by the industry and ultimately by investors. A professional bureaucracy must be built up to discharge effectively these responsibilities. ${ }^{82}$ Because of the higher pay scales in private industry, self-regulation is probably more costly than the increased staff necessary to carry on direct governmental regulation. Moreover, the cost of regulation, whether of a direct or self-regulatory character, need not be placed upon the public generally; an excise tax on the aggregate dollar amount of securities transactions sufficient to cover the cost of this phase of regulation would take care of this problem. Indeed, it seems unfortunate to this writer that a larger percentage of the cost of federal securities regulation is not obtained by increasing the various SEC filing fees and the existing securities transaction tax rather than

${ }^{80}$ Special Study, pt. 4 , at $722-28$.

${ }^{81}$ See the legislative committee reports recommending adoption of the Maloney Act. S. REP. No. I455, at 3-4, and H.R. Rep. No. 2307, at 4-5, 75th Cong., 2d Sess. (r938). And see Report of the Senate Committee on Banking and Currency Accompanying S. 1642, S. REP. No. 379, 88th Cong., Ist Sess. $42(1963)$.

${ }^{83}$ In I96r, the NYSE had total revenues of $\$ 23,930,639$ and total expenses of $\$ 20,430,551$. Special Study, pt. 4, at 516. It is impossible to determine the extent to which expenses represent the increment of cost arising from increased self-regulatory duties. It is apparent, however, that the Exchange's obligations entail very substantial expenditures. At the same time, the Special Study recommended that the NASD rely far less on "volunteers" and that there be a substantial increase in the professional staff so as to discharge adequately its regulatory responsibilities. Id., pt. 4 , at 680. 
by tapping the general revenues. ${ }^{83}$ This would place the burden of policing the securities industry where it belongs-on issuers, brokers and dealers initially and ultimately on investors. In any event, it is at least doubtful that the existing two-tier structure costs less than direct regulation.

Cost, however, is not the only factor to be taken into account. Self-regulation may be less cumbersome. The securities industry is in a position to carry on many of the regulatory activities perhaps more effectively than would be possible through the more remote means of direct regulation. Furthermore, industry self-government surely is psychologically more acceptable to the industry regardless of cost. Selfregulation has the further advantage of directly involving the industry in the regulatory process. No one likes external controls, least of all businessmen. Opportunity to participate in the regulatory process makes it much more palatable. As Mr. Justice Douglas, then Chairman of the Commission, put it: "Self-discipline is always more welcome than discipline imposed from above." ${ }^{\prime 34}$ And he cmphasized perhaps the most important advantage:

From the broad public viewpoint, such regulation can be far more effective [than direct regulation]. . . . Self-regulation . . . can be pervasive and subtle in its conditioning influence over business practices and business morality. By and large, government can operate satisfactorily only by proscription. That leaves untouched large areas of conduct and activity; some of it susceptible of government regulation but in fact too minute for satisfactory control; some of it lying beyond the periphery of the law in the realm of ethics and morality. Into these large areas self-government, and self-government alone, can effectively reach. For these reasons such self-regulation is by far the preferable course from all viewpoints. ${ }^{85}$

For these and other reasons the Commission, the Congress, and the industry seem justified in supporting the extension and refinement of the self-regulatory philosophy.

At the same time, however, the long history of stock exchange control by means of a large degree of self-government and recent disclosures with respect to policing of the over-the-counter markets suggest at least to this writer that there should be further extensions and improvements in governmental oversight. These reforms are long overdue. It is indeed a source of amazement that the stock exchanges

${ }^{83}$ The fees collected by the Commission for the fiscal year 1962 constituted only $30 \%$ of the total appropriation for Commission operations. These fees go into the general fund and are not available for expenditure by the Commission. Fees are collected for registration of securities, qualification of trust indentures, registration of exchanges and sale of copies of documents filed with thc Commission. The rates are exceedingly low: I/Ioo of I per cent of the maximum aggregate price of securities proposed to be offered but not less than $\$ 25$; and $\mathrm{I} / 500$ of I per cent of the aggregate dollar amount of stock transactions. Fees for other services are nominal. 28 SEC ANN. ReP. 166 (1962). For example, the filing fees for registration of a five million dollar issue under the Securities Act of 1933 is \$500, whereas the filing fee for qualification of the same issue under California Corporate Securities Law is $\$ r 298$. Cax. CoRps. Cone $\$ 26003$. The California fee schedule is undoubtedly too high in that the receipts from fees exceed the cost of regulation. At the same time, howcver, the federal fecs seem entirely too low.

84 Address before the Bond Club of Hartford, Connecticut, supra note 3. And see Westwood \& Howard, Self-Government in the Securities Industry, 17 LAw \& CONTEMP. Prop. 518 (1952); Cherrington, National Association of Securities Dealers, 27 HARv. Bus. Rev. 74I (I949).

${ }^{3 s}$ Address Before the Bond Club of Hartford, Connecticut, stipra note 3. 
have been able to preserve their autonomy and fend off reasonable governmental oversight in view of the important and strategic position which they occupy in the nation's economy.

Congress on numerous occasions has declared that the exchanges are "affected with a national public interest." "se The House Report on the Exchange Act put it this way:

The bill proceeds on the theory that the exchanges are public institutions which the public is invited to use for the purchase and sale of securities listed thereon, and are not private clubs to be conducted only in accordance with the interests of their members. The great exchanges of this country upon which millions of dollars of securities are sold are affected with a public interest in the same degree as any other great utility. The Commission is empowered, if the rules of the exchange in any important matter are not appropriate for the protection of investors or appropriate to insure fair dealing, to order such changes in the rules after due notice and hearings as it may deem necessary. The exchanges may alter their rules if more effective means are discovered to meet the same or new problems. Although a wide measure of initiative and responsibility is left with the exchanges, reserved control is in the Commission if the exchanges do not meet their responsibility. It is hoped that the effect of the bill will be to give to the well-managed exchanges that power necessary to enable them to effect themselves needed reforms and that the occasion for direct action by the Commission will not arise. ${ }^{87}$

It is believed that any such public institution to which has been "delegated governmental power" should be subject to greater governmental oversight in several respects. $^{\text {s8 }}$ Such supervision should continue to be vested in the Securities and Exchange Commission, "the official, expert guardian of the public interest in the field of securities. . . ."89

\section{A. Admission and Discipline of Members}

Memberships on the New York Stock Exchange are held by individuals rather than broker-dealer firms. "Member firms" (partnerships) and "member corporations" must have at least one general partner or director-shareholder who is a member of the Exchange. The general partners and voting shareholders of member firms who are not themselves members of the Exchange are known as "allied members." Under the Exchange constitution the Board of Governors must approve allied members and the formation of member firms and member corporations. ${ }^{90}$

Membership is attained by acquisition of a "seat" by gift or purchase. Any such acquisition is subject to approval by the Exchange. The Exchange screens the prospective member's qualifications with respect to integrity and competence when

${ }^{80}$ Sec $\$ 2$ of the Exchange Act, 48 Stat. 88x (1934), I5 U.S.C. $\$ 78 \mathrm{~b}$ (1958).

${ }^{87}$ H.R. REP. No. 1383 , 73d Cong., 2d Sess. 15 (1934).

${ }^{88}$ In Silver v. New York Stock Exch., supra note 29, at 37r. Mr. Justice Stewart, dissenting, said: "The purpose of the self-regulation provisions of the Securities Exchange Act was to delegate governmental power to working institutions which would undertake, at their own initiative, to enforce compliance with ethical as well as legal standards in a complex and changing industry."

${ }^{80}$ Special Study, pt. 4, at 724 .

${ }^{\circ}$ Id., pt. I, at 75 . 
he commences negotiations for the acquisition of a seat. ${ }^{21}$ The Special Study concluded that the Exchange's "screening, investigating, and testing program appears . . . to have operated effectively for the protection of the public."102 The Special Study adds that the program "appears to operate with considerable fairness from the point of view of the candidates too ...."13 It should not be overlooked, however, that the exchanges are semi-monopolies of immense economic power and that they exercise delegated governmental powers. ${ }^{94}$ For these reasons the conclusion reached by the Supreme Court in the Silver case seems inescapable: "Some form of review of exchange self-policing, whether by administrative agency or by the courts, is therefore not at all incompatible with the fulfillment of the aims of the Securities Exchange Act." ${ }^{\text {95 }}$ Indeed, such review seems essential to avoid serious constitutional problems arising from the delegation of unfettered governmental powers to the exchange. ${ }^{96}$

Analogies may be found for the type of governmental oversight by the SEC which is needed. For example, the pattern set in section $15 \mathrm{~A}$ of the Exchange Act with respect to SEC review of the self-policing functions of the NASD would fill the gap in existing governmental oversight of similar exchange activities. Accordingly, Congress should give the Commission statutory authority, on the Commission's own motion, or upon the application of any aggrieved person, to review denials of admission to membership on any of the registered exchanges. There should be a similar power with respect to admission to allied membership by virtue of an individual becoming a partner or shareholder in a member firm. Similar review powers should be given with respect to disciplinary actions taken against members, allied members, member organizations and registered representatives. As in the case of the NASD, the Commission should have the power to sustain the action of the exchange or to reduce or eliminate the penalty if it is found to be excessive or oppressive, but not to increase the penalty.

A somewhat different treatment of the review powers of a self-governing agency is to be found in legislation providing for self-regulation of the legal profession by

${ }^{81}$ Id., pt. I, at 75-79.

${ }^{82}$ Id. at 79. For a description of NYSE disciplinary procedures, see id., pt. 4 , at $536-44$.

${ }^{93}$ Id., pt. I, at 79 .

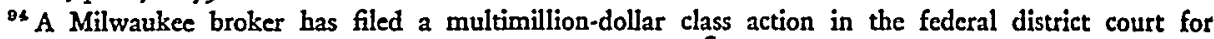
the eastern district of Wisconsin against the NYSE charging that the Exchange rule that prevents nonmembers from sharing in commissions on business they place through members violates the antitrust laws. The suit was brought on behalf of 4,000 nonmember brokers and dealers who are alleged to have been denied access to the trading facilities of the Exchange because of limited Exchange membership. Wall Street Journal, Oct. 2r, 1963, p. 2, col. 3. Regardless of the merits of this suit, serious legal and policy questions arise concerning restrictions on entry into the securities business and use of exchange facilities.

${ }^{25}$ Stipra note 29, at 359. Mr. Justice Goldberg, speaking for the majority, quotes SEC Chairman William L. Cary's observation that "some government oversight is warranted, indeed necessary, to insure that action in the name of self-regulation is neither discriminatory nor capricious." Cary, Self-Regulation in the Sectrities Industry, 49 A.B.A.J. 244, 246 (1963).

${ }^{\circ 0}$ Cf. Panama Ref. Co. v. Ryan, 293 U.S. 388, 421 (1935); A. L. A. Schecter Poultry Corp. v. United States, 295 U.S. 495, 529-30 (1935); Steele v. Louisville \& N. R.R., 323 U.S. 192, 204 (I944); Tunstall v. Brotherhood of Locomotive Firemen \& Enginemen, 323 U.S. 210 (1944); United States v. Philadelphia Nat'l Bank, 374 U.S. 321, 352 (1963). 
means of the integrated bar. In some twenty-six states all lawyers are required to belong to an official organization, the state bar association. ${ }^{97}$ The objectives of the integrated bars are somewhat analogous to those of the exchanges in policing their members and affiliated persons; in each case a major purpose is to regulate with respect to standards of admission and professional ethics and to establish efficient and fair disciplinary procedures to handle cases of misconduct. In every state where an integrated bar exists, the courts have formally retained their traditional disciplinary power over lawyers; and the disciplinary authority possessed by the state bar is by way of a recommendation to the Supreme Court. The Court has the power to follow the recommendations of the board of governors of the state bar or to increase or decrease the discipline imposed against a member. ${ }^{98}$ In California, which has an integrated bar, even though the Supreme Court is possessed with these powers, a study some years ago found no case where the Court imposed a greater degree of punishment than that of the state bar committee. ${ }^{90}$

The purpose of vesting review of disciplinary proceedings in the Securities and Exchange Commission would be primarily to protect the rights of the individuals concerned against capricious and arbitrary action by the exchanges. ${ }^{100}$ The very existence of the power of review would tend to cause the exchanges to undertake a continuous self-examination of their disciplinary procedures. The added burden on the Commission should not be excessive, based on the number of formal proceedings coming before the exchanges each year. ${ }^{101}$ If the institution of review proceedings operated as a stay of the action only when ordered by the Commission, after notice and hearing on the question, the legitimate interests of the exchange would seem to be adequately protected. The question remains whether it would be advisable to give the Commission the power to increase the penalty meted out by the exchange for violation of the rules of the exchange, within the limits imposed by exchange regulations. Aside from the factor of political expediency, the judicial reluctance to assert such admitted powers in disciplinary proceedings under the integrated bar acts indicates that it might be futile to give the Commission this additional power. ${ }^{102}$

\footnotetext{
${ }^{87}$ Lathrop v. Donohue, 367 U.S. 820,848 (I96r) (Harlan, J., dissenting). On the integrated bar movement, see Orie L. Phillips \& Philbrick McCoy, Conduct of Judges and Lawyers (I952); Glaser, Three Papers on the Integrated Bar (mimeo. Aug. Ig6o).

${ }^{8}$ Glaser, supra note 97. The California "integrated bar" act may be found in Car. Bus. \& Pror. CODE $\S \S 6000-6154$.

${ }^{\circ 0}$ Phillips \& McCoy, supra note 97, at 103. Curiously enough, these writers conclude that the Court and Bar have been too lenient in discipline cases. Id. at I00-04.

${ }^{100}$ Professor Walter Gellhorn has written forcefully and convincingly of the need for protection of the individual in his right to make a living. Although his chief concern was the occupational license, his observations are pertinent to the questions here considered. Walter Gellhorn, Individual Freedom and Governmental Restraints c. 3 (1956).

${ }^{102}$ From 1956-62 the number of formal disciplinary cases decided by the board of governors of the NYSE has averaged approximately eleven a year. Special Study, pt. 4, at 539 .

${ }^{102}$ See text at note 99 supra.
} 


\section{B. Enforcement of Rules of the Exchanges}

We have dealt with the matters of admissions and discipline from the standpoint of protection of the individual. On the other hand, when the enforcement of exchange rules are weighed in terms of the public interest and the protection of investors, it has been seen that the Commission lacks practical means of compelling an exchange and its members to adhere to exchange rules. ${ }^{103}$ As previously noted, section 6(b) of the Exchange Act requires that the rules of a registered exchange include provisions for disciplining members for conduct "inconsistent with just and equitable principles of trade." Section 6(d), in effect, commands that the rules of a registered exchange shall be "just and adequate to insure fair dealing and to protect investors." In the leading case of Baird $v$. Franklin, ${ }^{104}$ the court of appeals for the second circuit took the view that sections $6(\mathrm{~b})$ and $6(\mathrm{~d})$ impose "a twofold duty upon an exchange of enacting certain rules and regulations and of seeing that they are enforced."105 Accordingly, the court was of the view that failure of the officials of a registered exchange to take disciplinary action against a member after they know or have reason to believe that the member has violated an exchange rule (in this case a conversion of a customer's securities) may give rise to a private remedy against the exchange and its officials if prompt enforcement of exchange rules would have prevented loss to the customer. ${ }^{106}$ It is to be noted that this private remedy for willful or negligent failure to enforce exchange rules gives no protection against a member of the exchange who successfully conceals his misconduct so that the exchange has no reason to suspect any violation of its rules. Furthermore, not all rule violations will result in specific injury to a particular individual, yet they may be generally harmful to investors.

Aside from the possibility of a private remedy for negligent enforcement of exchange rules, the question arises whether the Commission should have some more direct way of obtaining compliance with the rules of the exchanges. This objective can be accomplished to a very great extent if the Commission will exercise its own rule-making powers under sections ro and II of the Exchange Act. Under section II the Commission, without employing the mechanism of self-regulation, may enact its own rules directly affecting the exchanges and their members with respect to floor trading, off-floor trading by members, and the activities of specialists and odd-lot dealers. Under section to the Commission may regulate with respect to short sales, stop-loss orders, and manipulative or deceptive devices and contrivances. We have noted that since the inception of the Exchange Act the Commission has followed the practice of "suggesting" that the exchanges adopt section Ix rules as rules of the

${ }^{108}$ See note 54 supra.

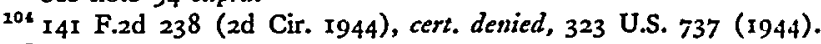

${ }^{205} 1 d$. at 244 (Clark, J., dissenting).

${ }^{208}$ Judges Swan and Augustus $N$. Hand acceded to this view but affirmed a finding for the defendant for failure to prove causation. The doctrine that such a private remedy exists was followed in Pettit $v$. American Stock Exch., 217 F. Supp. 2I (S.D.N.Y. 1963). 
exchange rather than for the Commission to take direct action and adopt such rules either alone or in conjunction with exchange rules covering the same ground.

In proposing new rule Ira-I restricting floor trading, the Commission, for the first time, would undertake direct action under its section II rule-making powers. ${ }^{107}$ If rule IIa-r is issued by the Commission, a member of the Exchange who violates the floor-trading rule of the Exchange would also violate rule Ira-r. The Commission has ample authority to issue its own rules not only on floor trading, but with respect to transactions by specialists and odd-lot transactions.

As has been seen, this approach has already been used by the Commission in regulating short selling. ${ }^{108}$ Section Io(a) of the Exchange Act empowers the Commission to make rules in the public interest and for the protection of investors with respect to short sales of securities registered on a national securities exchange; violations of such rules are declared to be unlawful. The Commission did not at first promulgate a rule on short selling; instead, in 1935, it "suggested" that the exchanges adopt the so-called Kennedy trading rules. ${ }^{109}$ One of these rules provided that a member should not effect a short sale at a price below the last sale price of such security on the exchange. ${ }^{110}$ This rule, designed to prevent short sales which had a demoralizing effect on the market, merely codified the existing stock exchange requirements which had been in effect since $193^{111}{ }^{111}$ After the market break of 1937 , the Commission re-examined the Exchange's short-selling rule, and as a result the Commission, in February 1938 , promulgated its own rules on short selling. ${ }^{112}$ The rule was relaxed somewhat in the following year as a result of extensive discussions between the Commission and NYSE officials. On several occasions since that time,

${ }^{107}$ Proposed rule rra-r in part provides:

(a) No member of a National Securities Exchange, while on the floor of such exchange, shall initiate, directly or indirectly, any transaction in any security admitted to trading on such exchange, for any account in which such member has an interest, or for any account with respect to which such member has discretion as to the time of execution, the choice of security to be bought or sold, the total amount of any security to be bought or sold, or whether any such transaction shall be one of purchase or sale.

(b) The provisions of paragraph (a) of this rule shall not apply to:

-...

(6) any transaction effected in conformity with a plan designed to eliminate floor trading activities which are not beneficial to the market and which plan has been adopted by an exchange and declared effective by the Commission. For the purpose of this rule, a plan filed with the Commission by a National Securities Exchange shall not become effective unless the Commission, having due regard for the maintenance of fair and orderly markets, for the public interest, and for the protection of investors, declares the plan to be effective.

....

SEC Securities Exchange Act Release No. 7290, April 9, I964.

${ }^{208}$ See note 57 supra. On the SEC short-selling rules, see 2 Louis Loss, Securities Regulation $1229-35$ (2d ed. 1961 ).

100 See p. 672 supra.

${ }^{110}$ I SEC ANn. ReP. 44 (I935).

111 See Special Study, pt. 2, at $25 \mathrm{I}$.

${ }_{112}$ Ibid. Rule 3b-3, I7 C.F.R. \$240.3b-3 (1949) defines a short sale; Rule roa-r(a), I7 C.F.R. $\$ 240.102-r(a)$ (1949), places restrictions on short sales. In general, short sales are prohibited unless made above the last sale price, usually by $1 / 8$ point or more, except that such sale may be made at the last price if that price was itself higher than the last preceding different price at which a sale, "regular way," was effected on the exchange. 
the NYSE has requested the Commission to make further modifications in the short sale rules but the Commission has refused to do so. ${ }^{113}$ This kind of direct action by the Commission seems to be precisely what the Congress envisaged under the reserve power "if the exchanges do not meet their responsibility." Such direct regulation is in no sense "an attack on Wall Street."

\section{Rule-Making by the Exchanges}

We have already noted that the rules of the exchanges must be filed with the Commission and that registration hinges upon a finding by the Commission that such rules are "just and adequate to insure fair dealing and to protect investors...." The Commission also may initiate specific changes in the rules and practices of a registered exchange with respect to those matters enumerated in section Ig(b) of the Exchange Act. ${ }^{116}$ Curiously enough, the Exchange Act does not expressly require the exchanges to notify the Commission in advance of any rule change, even if the rule change relates to the matters enumerated in section $I g(b)$. Under section 6(a) (4) a registered exchange is only required to furnish the Commission copies of any amendments to its rules "forthwith upon their adoption." The Commission has not been given the express power to abrogate even those rule changes which would fail to meet the standards imposed upon original registration.

The failure of the Exchange Act to give the Commission explicit authority to abrogate rule changes, even where the Commission can initiate changes, should not be construed to permit a registered exchange to defeat the purposes of the Exchange Act by first filing a constitution and set of rules that meet the standards of fairness to investors followed by later amendments which conflict with the standard. Although the Commission claims the power to compel advance filing, the NYSE denies any such authority. The NYSE, however, has agreed to give notice of changes, but does not concede that the Commission has authority to pass upon an amendment in advance of its adoption. ${ }^{117}$ Under these circumstances, the Exchange Act should be amended to eliminate this quibble by expressly giving the Commission the same powers to overrule changes by the exchanges as has been conferred with respect to the NASD and any other registered securities associations organized under section I5A of the Exchange Act. ${ }^{118}$ There appears to be absolutely no reason for this difference in treatment between the exchanges and the NASD.

\section{Compulsory Membership in the NASD or Other Registered Associations}

Under its current amendment program the Commission has proposed to remove the intrastate exemption in the broker-dealer registration provisions of section 15 of

\footnotetext{
${ }^{21 a}$ See Special Study, pt. 2, at 252.

${ }^{11}$ See p. 679 supra.

${ }^{215}$ Securities Exchange Act $\$ 6(d), 48$ Stat. 886 (1934), I5 U.S.C. $\$ 78 f(d)$ (1958); see p. 670 supra.

${ }^{116}$ See p. 67I and note 52 supra.

${ }^{117}$ See note $5 \mathrm{I}$ supra.

${ }^{218}$ For the Commission's authority to supervise NASD rule changes, see p. 676 supra.
} 
the Exchange Act. ${ }^{119}$ Thus, any broker or dealer who uses the mails to effect transactions in any security (with some exceptions) otherwise than on a national securities exchange would have to register with the Commission in accordance with section $15(\mathrm{~b})$. The bill as passed by the Senate removes the intrastate exemption, ${ }^{120}$ but the House bill, as amended by the Subcommittee on Commerce and Finance of the House Committee on Interstate and Foreign Commerce, would continue to exclude from registration any broker or dealer "whose business is exclusively intrastate." 121

At the same time, however, both the House and Senate bills require that all brokers and dealers registered under section 15 (b) also be members of a securities association registered under section ${ }_{55} \mathrm{~A}$ of the Exchange Act. ${ }^{122}$ Section ${ }^{15} \mathrm{~A}$ would also be amended to provide that registered associations must adopt rules establishing standards of training, experience, competence, and financial responsibility for members and their employees. ${ }^{123}$ Under sections $\eta(a)(2)$ and (4) of these bills, the association would be authorized to expel a member. Thus, the NASD or any other registered association would be allowed, indeed required, to establish professional standards for persons engaged in the securities business as principals or as registered representatives, and to police the industry by enforcing disciplinary rules subject, of course, to Commission review. The Commission justifies these proposals on the marked expansion taking place in the numbers of securities firms and registered representatives since 1945 and the need for raising standards of fitness, competence and financial responsibility of persons engaged in the securities business. Chairman William L. Cary has put it this way:

The steady growth in the number of investors, the complex nature of the securities markets, the reliance which the investing public necessarily places upon the competence and character of professionals in those markets: all of these factors militate against continuation of the existing ease of entry and of the lack of qualification standards. These conditions subject the public to undue hazards and unnecessarily complicate the task of regulation. ${ }^{124}$

This proposal for compulsory membership in the NASD or similar organization (with authority in the Commission to grant exemptions where necessary and appropriate) would force about 300 firms to join a registered securities association performing self-regulatory functions in order to continue in the securities business. ${ }^{125}$ Among the firms affected would be some of the large mutual fund sales organiza-

\footnotetext{
${ }^{110}$ See statement of SEC Chairman William L. Cary, in Hearings Before the Subcomm. on Securities of the Senate Comm. on Banking and Currency, on S. 1642, 88th Cong., Ist Sess. 60 (1963).

${ }^{120}$ S. $1642, \S 6(\mathrm{a})$. S. REP. No. 379 , 88th Cong., Ist Sess. 46 (1963).

${ }^{131}$ H.R. $6793, \$ 6(a)$, as approved by the Subcommittee on Commerce and Finance of the House Committee on Interstate and Foreign Commerce for consideration by the full committee. The bill has since been reported by the House Committee. See H.R. REP. No. I418, 88th Cong., 2d Sess. (1964).

${ }^{122}$ S. 1642 , H.R. 6793, $\$ 6(\mathrm{a}), 88$ th Cong., Ist Sess. (1964).

${ }^{138}$ S. 1642 , H.R. $6793, \S 7(a), 88$ th Cong., Ist Sess. (1964).

${ }^{124}$ Statement of Chairman Cary, in Hearings, supra note II9, at 45.

${ }^{226}$ Id. at 43 . S. ReP. No. 379, 88th Cong., Ist Sess. 43 (I963).
} 
tions with several thousand salesmen. Strong opposition has come from these organizations; they object to the legislation on the basis of policy and supposed unconstitutionality.

Although it is possible to make noises of unconstitutionality concerning a guild system of securities control, it is believed that recent cases concerning compulsory membership in professional associations and in labor unions foreclose constitutional issues under the first and fifth amendments. Constitutional objections to state-compelled membership in an integrated bar were rejected in Lathrop $v$. Donohue ${ }^{126}$ because of the state's interest in fostering the public purposes served by a bar association made up of all lawyers practicing within the state. Furthermore, in Lathrop, the rule-making and disciplinary powers of the bar association were subject to supervision by the Wisconsin Supreme Court upon the complaint of any member. ${ }^{127}$ In Railway Employees Dep't v. Hanson, ${ }^{128}$ a federal statute compelling an employee to join a labor union and pay dues in order to continue employment was sustained on the theory that one who receives the benefits of collective bargaining should contribute to its support. In the Court's view, Congress' power to regulate labor relations in interstate industries permitted a union shop to be fostered as a stabilizing force in facilitating industrial peace. At the same time, however, certain limits are imposed upon such associations with a captive membership. Thus, they may be constitutionally prohibited from supporting issues not fairly related to the association's objectives. ${ }^{129}$ Aside from these limitations, section $15 \mathrm{~A}$ as proposed to be amended gives the SEC broad supervision over the operations of registered associations sufficient to prevent a constitutional attack based upon a claim of improper delegation of legislative powers. ${ }^{130}$

Some of the objections based on policy grounds are that: (I) the power to determine whether a person or firm could commence or remain in business would be vested in an association made up of business competitors; (2) the persons exercising these judicial functions might be engaged in a competing mutual fund business or might be brokers or dealers in competition with the funds; (3) members of the association might be compelled to divulge the details of their business operations to the association, and thus, indirectly to competitors; (4) self-regulation is incompatible with compulsory membership in the self-regulatory body. ${ }^{181}$ The opponents of compulsory membership in a self-regulatory body urge that they are

${ }^{126}{ }_{367}$ U.S. 820 (196r).

${ }^{127}$ Id. at 825. And see In re Integration of the Bar, 5 Wis. $2 \mathrm{~d} 618,93$ N.W.2d 601 (1958). For a discussion of constitutional restrictions on private associations, see Developments in the Law-Indicial Control of Actions of Private Associations, 76 HARv. L. REv. 983, 1058-69 (1963).

${ }^{128} 351$ U.S. 225 (1956).

139 Lathrop v. Donohue, supra note 126; International Ass'n of Machinists v. Strcet, 367 U.S. 740 (196I); Brotherhood of Ry. \& S.S. Clerks v. Allen, 373 U.S. 113 (1963). See Developments in the Law, supra note $127, \mathrm{I06}_{4}-67$.

${ }^{130}$ See note 96 supra.

132 See testimony of $\mathrm{Mr}$. Arthur V. Toupin, general counsel of Insurance Securities, Inc., in Hearings on H.R. 6789, H.R. 6793, S. 1642 , supre note 9, pt. 2, at $836-45$. 
already subject to ample direct regulation, but that if additional regulation is necessary, it should be given to the Commission directly rather than to an association of competitors. ${ }^{132}$

This line of argument has frequently been advanced by opponents of the idea of an integrated state bar. ${ }^{133}$ Yet in a number of states these compulsory associations have marked up a notable record of achievement in raising standards of the profession and in carrying on important public service activities. Although there have been complaints that the NASD is dominated and controlled by New York Stock Exchange members to the prejudice of those firms engaged exclusively in an over-thecounter business, ${ }^{134}$ the NASD seems generally to have merited the support and confidence of the overwhelming majority of securities brokers and dealers. Nevertheless, there is a conflict of interest between NYSE member firms and the small nonmember over-the-counter firms. The heart of the stock exchange system is based upon a restricted membership; a preferential commission rate schedule on dealings between members; the setting of minimum commission rates charged to all outsiders, including nonmember professionals and institutional investors; and the ban on sharing commissions with nonmember firms who perforce must place orders on stock exchange transactions on the Big Board through a member firm. ${ }^{135}$ Thus, the small over-the-counter firm is placed in the position where it must accept such NYSE business as is placed with it for fear of losing its customer; and even though it has certain fixed overhead costs, competition with NYSE member firms precludes it from charging an additional commission to that charged by the member firm for executing the order. The monopoly power of the stock exchanges, and particularly of the Big Board, as well as the present autonomous position of the registered exchanges under the Exchange Act, raise the question of the extent to which the courts may use the antitrust laws to intervene in stock exchange affairs to protect nonmembers (and even members) from anti-competitive practices which thwart the grand design of the Exchange Act or to prevent arbitrary or capricious actions against such persons.

In the Silver case a nonmember broker-dealer applied to the NYSE for directwire telephone connections with a member firm. Temporary approval was granted and the connections established. Later, the Exchange ordered the member firm to terminate such connections which it was compelled to do under an Exchange rule on file with the Commission. ${ }^{136}$ The Court held that the self-regulatory duties imposed on the NYSE by the Exchange Act did not exempt it from the antitrust laws nor

${ }^{109} \mathrm{Id}$. at 840 .

${ }^{193}$ The arguments for and against bar integration, as they appear in the professional literature, are summarized in Glaser, supra note 97, pt. 2, at 20-30; Gilb, The State Bar Idea, 34 CAL. ST. B.J. 866, $870-82$ (1959).

${ }_{186}$ N.Y. Times, Jan. 28,1964, p. 2, col. 3 .

${ }^{196}$ For a discussion of the structural aspects of stock exchange commission rates, see Special Study, pt. 2, at 294-351.

${ }^{180}$ See p. 668 supra. 
justify it in enforcing the rule without according Silver the notice and hearing which he had requested. The Court noted that had the concerted action of the Exchange and its members occurred in a context free of federal regulation under the Exchange Act it would have been a per se violation of section $\mathrm{I}$ of the Sherman Act. A majority concluded that since the Exchange Act contains no express exemption from the antitrust laws, repeal would be implied only if necessary to effectuate the broad objectives of the Exchange Act. The Court emphasized that the act failed to give the Commission the jurisdiction to review particular instances of enforcement of exchange rules, as had been done with the NASD. Therefore, there was "nothing built into the regulatory scheme which performs the antitrust function of insuring that an exchange will not in some cases apply its rules so as to do injury to competition which cannot be justified as furthering legitimate self-regulative ends."137 Government oversight was necessary to make sure that Exchange action taken in the name of self-regulation was not discriminatory, arbitrary, or capricious. In the absence of SEC supervision, the vacuum was to be filled by judicial enforcement of the antitrust laws. And Justice Goldberg concluded:

What is basically at issue here is whether the type of partnership between government and private enterprise that marks the design of the Securities Exchange Act of 1934 can operate effectively to insure the maintenance of such standards in the long run. We have today provided not a brake upon the private partner executing the public policy of selfregulation but a balance wheel to insure that it can perform this necessary activity in a setting compatible with the objectives of both the antitrust laws and the Securities Exchange Act. ${ }^{138}$

Although the precise limits of the doctrine announced in the Silver case are yet to be determined, perhaps other anticompetitive conduct of the Exchange such as that built into the commission rate structure (which is highly discriminatory to nonmembers) may give rise to injunction and treble damage actions under the Sherman Act.

The Thill Securities Corp. suit against the New York Stock Exchange, previously referred to, ${ }^{139}$ is framed on the theory that the NYSE rules preventing member firms from splitting commissions with nonmember firms on business the latter brings to the Exchange violate the antitrust laws. Although the Commission has broad powers under section $I 9$ (b) to alter the commission rate structure, so far it has not tackled the discrimination between member and nonmember firms entailed therein. However, the NYSE rules against rebates are riddled with exceptions based upon "reciprocal business arrangements," "140 "special services"141 to nonmember firms,

${ }^{137}$ Silver v. New York Stock Exch., supra note 29, at 358 .

${ }^{288}$ Id. at $366-67$. Following remand of the Silver case, the NYSE settled the \$I million suit for $\$ 375,000$. Wall Street Journal, May 20, 1964, p. 3, col. 4 .

139 See note 94 supra.

${ }^{140}$ Special Study, pt. 2, at 302-07.

141 Id., pt. 2, at 307-10. 
and other subtle arrangements to circumvent the rigid rules against rebates. ${ }^{142}$ On the other hand, the Exchange has refused to modify its rules so as to provide for quantity discounts to large-volume purchasers, either professional or institutional. ${ }^{143}$ Unfortunately, this inflexible policy against quantity discounts has in turn given rise to the "give-up or directed split"144 as well as to various reciprocal arrangements. Until the Exchange and the Commission come to grips with the problems generated by the current rate structure, the Exchange may well be vulnerable to suits under the antitrust laws.

It is doubtful that the exchanges can continue to operate while sitting underneath the sword of Damocles represented by the antitrust laws. A practical solution would be for the exchanges and the SEC to join in a proposal to Congress that registered exchanges be granted statutory immunity from the antitrust laws in return for an expansion of SEC supervisory powers along the lines here suggested. In order to protect individual brokers and dealers from arbitrary or oppressive group action, the statute should accord a member or nonmember of an exchange the right to a hearing before the exchange's governing body before policies or practices affecting him are finally determined. Furthermore, those persons should have the right of appeal to the Securities and Exchange Commission after the exhaustion of remedies at the level of the exchange. The Reed-Bulwinkle Act granting antitrust immunity with respect to certain rate agreements among carriers subject to the jurisdiction of the Interstate Commerce Commission (ICC) provides an analogy and precedent for this type of procedure. ${ }^{145}$ That act, passed in 1948, authorizes common carriers to apply to the ICC for approval of agreements ". . . relating to rates, fares, classifications, divisions, allowances or charges ... or rules and regulations pertaining thereto, or procedures for the joint consideration, initiation or establishment thereof. . .."148 Approval by the ICC will relieve the parties from the operation of the antitrust laws in making and effectuating any such agreement, if carried out in conformity with the terms and conditions prescribed by the ICC. The Commission is to grant approval of an agreement only if it finds that relief from the operation of the antitrust laws would further the national transportation policy established by the Interstate Commerce Act. Moreover, the act specifically provides that approval shall be denied to any agreement which establishes procedures for the joint determination of any matter by a group of carriers unless the Commission finds that "under the agreement there is accorded to each party the free and unrestrained right to take independent action either before or after any determination arrived at through such procedure."147 The latter provision is designed to protect particular carriers

${ }^{142}$ For a description of the variety of "special services" currently being furnished by member firms without payment other than the receipt of commission business, see id., pt. 2, at 312-13.

${ }^{148} I d$., pt. 2, at 3II-I2.

III Id., pt. 2, at $316-18$.

${ }^{115} 62$ Stat. 472 (1948), 49 U.S.C. $\$ 5$ b (1958).

${ }^{248}$ Reed-Bulwinkle Act $\$ 5 \mathrm{a}(2), 62$ Stat. 472 (I948), 49 U.S.C. $\$ 5$ b(2) (I958).

${ }_{117}$ Reed-Bulwinkle Act $\S 5$ (6), 62 Stat. 473 (1948), 49 U.S.C. $\$ 5$ (b)(6) (1958). See CARL. H. Fulda, Competition in the Regulated Industries-Transportation 283-309 (I961). 
from arbitrary or oppressive group action. It thus provides an excellent model for similar legislation applicable to registered exchanges.

\section{Conclusron}

As this paper goes to press, the fate of the proposal calling for mandatory membership of brokers and dealers in a registered securities association is in doubt. The House Committee on Interstate Commerce has approved the House bill, after eliminating the provisions which would require brokers and dealers using the mails or interstate facilities for securities transactions to belong either to the NASD or a similar association registered under section $15 \mathrm{~A}$ of the Exchange Act. ${ }^{148}$ Instead, the new version would allow a choice between membership in such a selfregulatory agency or similar direct regulation by the Securities and Exchange Commission. A number of the large mutual fund sales organizations have indicated a preference for the latter form of regulation. In such event, they should be required to bear the cost of this additional form of regulation. ${ }^{140}$ If the Securities Act amendments of 1964 are adopted, they will go a long way towards improving standards of investor protection for securities traded in the over-the-counter markets.

This leaves the supervisory role of the Commission vis à vis the exchanges for future solution. The suggestions here made are in my opinion reasonable and, in the long run, they are conservative. It may well. be that the historical conception that the Exchange is a private club is the principal stumbling block to the moderate reforms of the sort here suggested. The Supreme Court has now confirmed the general community feeling that this "private club" concept belongs to a simpler age and is no longer valid. Once this dogma is dispelled, as it must be, we may be able to engage in a rational debate on the improvements needed to allow the Exchange to play its proper role in our modern economy.

${ }^{143}$ N.Y: Times, May 8,1964 , p. 43 , col. I.

${ }^{150}$ A House Appropriations subcommittee which is currently considering the SEC $\$ 15,225,000$ budget request for the fiscal year ending June 30,1965 is reported to be prodding the Commission to raise its fee schedule in order to shift to the securities industry more of the cost of regulation. Fees currently collected bring in only $\$ 3,000,000$ a year. Wall Street Journal, May 13, 1964, p. 4, col. 2. And sec note 83 stipra. 